\title{
ANTIQUITY
}

(the spade is non-existent in these countries), and I never knew before that a digging-stick is exactly like an oar to look at, and that you use it exactly like a paddle, the blow falling just outside your left foot (or right foot if you are left-handed). A capable user of the digging-stick can turn a furrow with it that looks just like a ploughed furrow, so that in that tribe's country I thought at first, to judge by the fields, that they must have ploughs. As for lynchets, I never dreamed of the like. Sawah-agriculture, for growing rice, is all done in plots of land each one of which is levelled and surrounded with an earth rim, so that it can be flooded. Believe it or not, they will make sawahs on a slope of $45^{\circ}$, each sawah $4 \mathrm{ft}$. wide, with a 4 -ft. vertical earth scarp above and below it; and they will lift their ploughs up and down these scarps, and the buffaloes for ploughing will scramble up and down by means of a step, and never injure the earth rims of the sawahs in doing so. They think it quite worth while to take a plough and a couple of buffaloes into a sawah measuring 4 by 6 feet; that is an extreme case, but on steep ground sawahs of 8 by 12 are not at all rare'.

\section{THE SUTTON HOO SHIP BUILT IN SWEDEN?}

In recent years it has been argued convincingly by R. L. S. Bruce-Mitford that the Sutton Hoo find points to the fact that the man who founded the East Anglian dynasty C. A.D. $55^{\circ}$ was of Swedish origin. 'All the phenomena in the Sutton Hoo ship-burial that we have discussed ', he points out, ' are perfectly explicable if we suppose that Nerman's Swedish conqueror established his control over East Anglia not at the period of our burial - mid-7th century-but a good deal earlier; in fact, that he was the man who founded the East Anglian dynasty in the mid-6th century. What we find in the burial would then be Swedish heirlooms (sword, helmet, shield) treasured as symbols of the origins or history of the royal house. . ...'1

It is the purpose of this note to suggest that there is evidence that the Sutton Hoo ship itself was of Swedish construction; that it may even have been one of the vessels in which 'Nerman's Swedish conqueror' crossed to England to found the East Anglian dynasty C. A.D. $55^{\circ}$.

Anyone who reads the poem Beowulf and then studies the construction of the Sutton Hoo ship must be struck by the fact that the poet speaks almost nonchalantly of masts and sails whereas the Sutton Hoo vessel is said to have contained no provision for a mast. Miss Dorothy Whitelock has drawn attention to this contradiction in The Audience of Beowulf (Oxford, I95I, p. 84): ' Scyld's ship had a mast, whereas the Sutton Hoo ship was mastless, but this need not be a significant discrepancy, for one cannot argue from one ship without a mast that sailing ships were unknown at the date of the Sutton Hoo burial'.

Now it is obvious from evidence both inside and outside Beowulf that sailing ships were the very reverse of 'unknown' among the Anglo-Saxons for centuries before the Sutton Hoo burial. Admittedly the poem was composed somewhere between 700 and 790 , while the ship was buried about $65^{\circ}$, but the poet writes as if he and his listeners had never heard of a time when their ancestors were not building ships with masts and sails, even when he is describing ships built centuries earlier. To him the sea is, and has been for centuries, the 'sail-road' (segl-räd, 1.1429), and in lines 36,217 , and 1905-6 there are further casual references to masts, sails and rigging.

This evidence is corroborated by that from the classical writers. In his article The

1 Proceedings of the Suffolk Institute of Archaeology, vol. 25, part I (1949), p. 74. See also the same writer's Appendix to R. H. Hodgkin's History of the Anglo-Saxons, $3^{\text {rd }}$ ed., Oxford, 1952, pp. 721-4. 


\section{NOTES AND NEWS}

Nydam Craft and the Anglo-Saxon Invasions in The Mariner's Mirror of Feb. 1955 (vol. 41, no. I) G. J. Marcus writes: 'What is perfectly clear from both classical and British sources is that towards the close of the Imperial period the Saxon raiders came over in sailing craft'. He points out that the poet Claudian, writing in the $4^{\text {th }}$ century, implies in $D e$ consulatu Stilichonis that the Saxon vessels were dependent on the wind. In the following

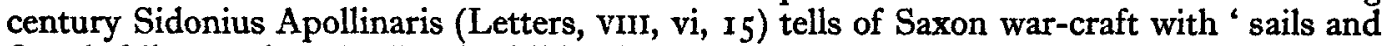
firm-holding anchors '. Lastly Gildas (De excidio, ch. 23) says that some Saxon settlers sailed over, in the middle of the $5^{\text {th }}$ century, with a favouring wind, secundis vellis.

The upshot of all this is that, if it can be proved beyond doubt that the Sutton Hoo ship had no provision for a mast, then the only way we can explain the appearance of such a ship in the England of A.D. 650 is to look elsewhere for a civilization where a mastless ship of that size could have been built at that time. There is some evidence that there was such a civilization in southern Scandinavia about that time. In their book The Viking Ships (p. $5^{8}$ of the 1953 English edition) Brøgger and Shetelig describe how the use of masts and sails reached that region between A.D. 600 and 900. 'What now remains to be accomplished in boat-building,' they write, 'is the achievement of full strength and solidity in the keel part, so that they could raise a proper mast and employ sail at sea in all weathers. This takes place in the centuries between the Kvalsund ship and the Gokstad ship, the years from 600 to 900 . . . . It was through these innovations of keel and crosspieces, which may look simple enough, that it became possible to give the ship an efficient spread of sail '.

The Sutton Hoo ship was old when buried about A.D. 650, to judge from patches on its hull. If it had been 'treasured as symbol of the origin or history of the royal house', it may not be impossible that it was nearly roo years old when buried, a relic of the period when there was close contact between East Anglia and East Scandinavia. As Mr BruceMitford has pointed out (1952, p. 722): "The occurrence of boat-graves elsewhere in Suffolk shows that the Swedish element, if such there be, occurs on a broader front, and the traces of Swedish influences in locally made archaeological pieces, both in this grave and outside it, indicate a sustained and dynamic Swedish element, not a casual and negative one.' It may easily be that the ship itself represents part of this Swedish element, for how else can we explain the fact that a people who had been building masted ships for centuries, as the ancestors of the Beowulf poet had apparently been doing should build a vessel of the size of the Sutton Hoo ship to be driven by thirty-eight oars alone? It may be that further study of the Sutton Hoo evidence, in conjunction with the growing body of information from Sweden, will throw further light on this possibility.

N. E. LEE. 